\title{
PROCEEDINGS
}

OF THE

\section{American Society of} International Law

AT ITS

FORTY-NINTH ANNUAL MEETING

HELD AT

WASHINGTON, D. C.

APRIL 28-30, 1955

PUBLISHED BY THE SOCIETY

1826 Jefrerson Place, N.W

WASHINGTON 6, D. C.

1955

Reprinted with the permission of the original publisher

KRAUS REPRINT CORPORATION

New York

1968 


\section{Copyright (C) 1955 By}

The American Society of International Law

It is the policy of the American Society of International Law not to take an official position, by resolution or otherwise, upon controversial questions. The views expressed in the addresses and remarks delivered at its annual meetings and appearing in its printed Procendings are those of the individual speakers and are not to be taken as representing the views of the Society.

Printed in U.S.A. 


\section{TABLE OF CONTENTS}

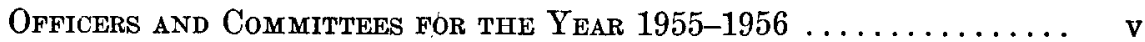
InCORPoration ACT of September $20,1950 \ldots \ldots \ldots \ldots \ldots \ldots$ viii Resolution of April $28,1951 \ldots \ldots \ldots \ldots \ldots \ldots \ldots \ldots \ldots \ldots$ xi Constitution of the American Society of International Law ... xiii Regulations of the Society $\ldots \ldots \ldots \ldots \ldots \ldots \ldots \ldots$ vii

First Session

Thursday, April 28, 1955, at 8:15 P.M.

Address, “Power, Facts and Law," by President Philip C. Jessup ... 1

Remarks: Herbert $W$. Briggs ...................... 11

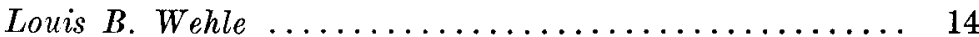

Hardy C. Dillard ....................... 18

\section{Second Session}

Friday, April 29, 1955, at 9:30 A.m.

PANeL I

Recent Developments in Regional Organization

Address by Norman J. Padelford ....................... 23

Remarks : Joseph W. Bishop, Jr. .................. 41

Kurt Steiner ......................... 44

Alwyn V. Freeman ..................... 47

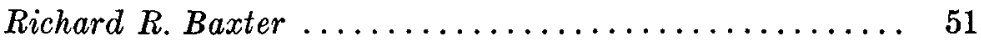

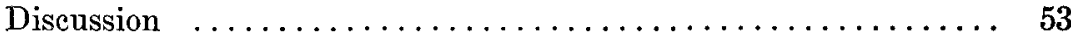

Rapporteur: Brownlee S. Corrin

Third Session

Friday, April 29, 1955, at 2:30 P.M.

Panel II

Practice and Procedure before International Claims Commissions, including General Principles and Techniques of Effective Presentation of Claims

Address, "International Claims: A Lawyer's View on a Diplomat's Nightmare," by Dudley B. Bonsal ................... 62

Remarks: Honorable Whitney Gillilland ............... 72

Martin Domke ....................... 76

Douglas E. Dayton ...................... 78

Discussion ............................... 80

Rapporteur: William G. Bowdler 


\section{Fourth Session}

Friday, April 29, 1955, at $8: 15$ P.M.

PANel III

International Law and Current Problems in the Far East

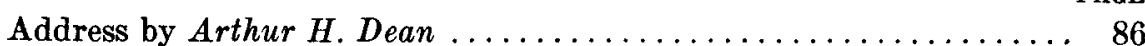

Remarks: Honorable Herman Phleger ................. 98

Honorable Stanley K. Hornbeck ............... 99

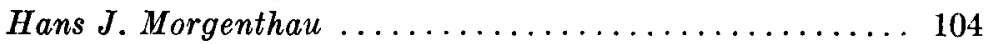

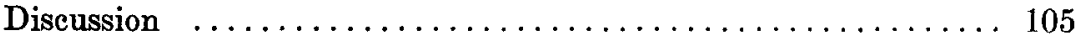

Rapporteur: Robert W. Tucker

\section{Fifth Session}

Saturday, April 30, 1955, at 10:00 A.m.

Business Meeting

In Memoriam

Reports of Committees:

Committee on Study of Legal Problems of the United Nations ..... 111

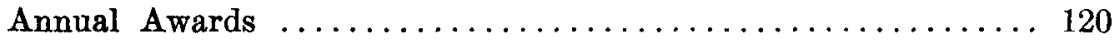

Selection of Honorary Members $\ldots \ldots \ldots \ldots \ldots \ldots \ldots \ldots \ldots \ldots$

Financing and Endowment $\ldots \ldots \ldots \ldots \ldots \ldots \ldots \ldots \ldots \ldots \ldots \ldots$

Publications of the Department of State ................ 121

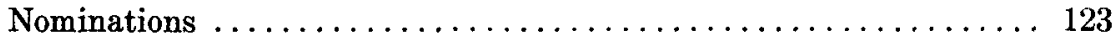

Resolution on Publication of United States Treaty Developments ... 121

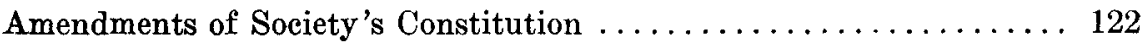

Election of Officers ............................... 123

\section{Annual Dinner}

Saturday, April 30, 1955, at 7:00 P.M.

Address, "Atoms for Peace and the International Community," by Ambassador Morehead Patterson ...................... 125

Address, "The Present-Day Rôle of the Security Council in the Maintenance of Peace,"' by His Excellency Sir Leslie Munro, K.C. M. G. 131 Address, "The United Nations and the Future," by the Honorable John J. Sparkman ......................... 136

\section{Appendix}

Report of Commitsee on Study of Legal Problems of the United

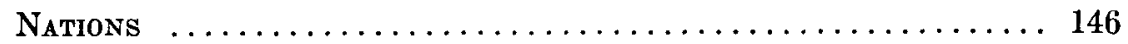

Report of Committee on Publications of the Department of State 166

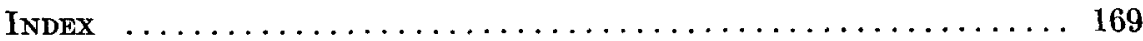

